\title{
Количественный анализ структуры лесных и степных участков Донецкой области
}

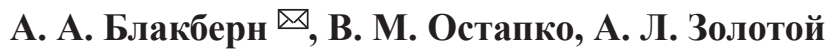 \\ Донеикий ботанический сад, Украина \\ (83059, г. Донеик, пр. Ильича, 110)
}

\begin{abstract}
Аннотация: Цель исследования - предварительная инвентаризация и сравнительная количественная оценка природных участков ряда административно-территориальных подразделений (АТП) Донецкой области.

Объекты и методы: методом визуализации космоснимков из свободного доступа спутника Sentinel2А и компьютерной программы QGIS определены количество, площади, показатели фрагментированности двух основных типов природных (квазиприродных) экосистем региона - степных и лесопокрытых территорий в границах трех районов (Шахтерского, Амвросиевского, Старобешевского) и Донецко-Макеевской агломерации.

Результаты: показано, что, несмотря на количественное преобладание лесопокрытых участков над степными, последние значительно превышают первые по занимаемым площадям, что свидетельствует о степном характере ландшафта в целом.

Как степные, так и лесопокрытые территории имеют высокую степень фрагментации, которая не зависит от нижнего предела площади отдельного участка (все рассматриваемые участки, участки площадью более 1 га и участки площадью более 3 га).

По совокупности обоих типов природных территорий наиболее богат ими Шахтерский район, за ним следует Амвросиевский район (оба находятся в восточной части Донецкой области), за ними идет Донецко-Макеевская агломерация и на последнем месте находится Старобешевский район. В целом все природные (квазиприродные) территории исследованных АТП занимают 21 \% от их площади, что свидетельствует о невысоком уровне сохранности экологического каркаса в данной части Донбасса.

Анализ пространственной структуры экологического каркаса в исследованных АТП показал, что наиболее негативно на его разнообразие влияет аграрное использование ландшафта, а не степень урбанизации. А наиболее положительным фактором сохранения природного разнообразия является сложность структуры рельефа территории.
\end{abstract}

Ключевые слова: экологический каркас, экологическая сеть, степные и лесопокрытые территории, показатели фрагментированности территории, космоснимки, программа QGIS.

Для цитирования: Блакберн А. А., Остапко В. М., Золотой А. Л. Количественный анализ структуры лесных и степных участков Донецкой области // Вестник Воронежского государственного университета. Серия: География. Геоэкология, 2021, № 1, с. 25-36. DOI: https://doi.org/10.17308/geo.2021.1/3253

\section{ВВЕДЕНИЕ}

Современная экосетевая парадигма в природоохранной политике предполагает обеспечение соответствующей охраной всех природных и природно-антропогенных (полуприродных) участков территории любого масштаба с целью сохранения всего ее биологического и ландшафтного разнообразия, а не только охрану раритетных видов организмов и их сообществ.
В этой связи очень важно знать и реально оценить существующую структуру всех природных и природно-антропогенных компонентов экологического каркаса исследуемой территории, физически связанных между собой в едином пространстве общностью информационно-вещественно-энергетических процессов.

Помимо созологического аспекта в сохранении экологического каркаса территории, суще-

(C) А. А. Блакберн, В. М. Остапко, А. Л. Золотой, 2021

$\triangle$ Блакберн Андрей Альфредович, e-mail: blackburn.fox@mail.ru 
ствует проблема оптимизации ее ландшафтной структуры с позиции устойчивого и неистощительного взаимодействия её природных компонентов и хозяйствующего субъекта. В основе такой оптимизации лежит объективная оценка структурных элементов и придание им определенного официального статуса в составе экологической сети. Иначе говоря, экологическая сеть вместе с системой особо охраняемых природных территорий (ООПТ) - это правовая форма оформления и защиты всего экологического каркаса. И здесь очень важна количественная оценка его пространственной структуры [2].

Целью данной статьи является предварительная инвентаризация и сравнительная количественная оценка природных участков на территории трех административных районов (Шахтерского, Амвросиевского и Старобешевского) и двух городов (Донецка и Макеевки) Донецкой области.

Авторами были поставлены следующие задачи: 1) апробировать метод визуального определения предполагаемых степных и лесных участков с использованием космоснимков из свободного доступа спутника Sentinel-2A и компьютерной программы QGIS; 2) определить основные количественные параметры (площадь, средняя площадь, степень фрагментации) выявленных участков в территориальной структуре исследуемых городов и районов; 3) провести сравнительную оценку количественного распределения выделенных участков путем ранжированияих по занимаемым площадям на исследуемых административно-территориальных подразделениях.

\section{ОБЪЕКТЫ И МЕТОДИКА ИССЛЕДОВАНИЯ}

В качестве объектов данного исследования были взяты два класса наиболее распространенных в регионе природных территорий - степные и лесные участки в границах трех административных районов - в Шахтерском, Амвросиевском и Старобешевском, и двух городов - Донецке и Макеевке.

Под степными участками на данном этапе исследования условно были приняты все площади как с естественной, преимущественно травянистой растительностью, без их дифференциации на луговые, кустарниковые, петрофитные, псаммофитные степи и обнажения каменистых пород, целинные и антропогенно нарушенные без трансформации исходного типа растительности, так и с антропогенно-измененным покровом: залежи на месте постстепных полей в различной степени восстановительной сукцессии и сбитые пастби- ща. Лесные участки нами определялись как лесопокрытые территории независимо от их происхождения, конфигурации, типов и подтипов леса или древесно-кустарниковых насаждений.

Выбранные административно-территориальные подразделения - районы и города Донецкой области расположены в центральной и восточной ее части (рис.1).

Шахтерский и Амвросиевский районы находятся в восточной части и согласно физико-географическому районированию расположены в одноименной возвышенной области Донецкой северо-степной провинции [5].

Шахтерский район расположен на южном и юго-западном макросклонах Донецкого кряжа - главного геоморфологического образования региона. Вследствие этого Шахтерский район имеет очень сложную, преимущественно холмисто-грядовую структуру рельефа. В структуре природной растительности преобладают типичные (разнотравно-типчаково-ковыльные) и петрофитные степи, а также байрачные леса, плотность которых здесь одна из самых высоких в Донбассе. Кроме того, Шахтерский район самый урбанизированный в Донецкой области. На его территории располагаются четыре города с населением свыше 70 тыс. человек в каждом и множество поселков городского типа.

Амвросиевский район граничит с юга с Шахтерским. Имеет более сглаженную структуру рельефа - холмисто-грядовую только на севере и преимущественно равнинную на всей остальной части. Структура хозяйства в районе преимущественно аграрная. Степень урбанизации невысокая.

Города Донецк и Макеевка находятся в центральной части Донецкой области, образуя единый урбанизированный комплекс - Донецко-Макеевскую агломерацию. В своих административных границах оба города имеют значительные площади аграрного типа ландшафтов, включающего также природные и полуприродные участки. В большей степени данный тип ландшафтов характерен для Макеевки, особенно в северной, восточной и юго-восточной части. С позиции физико-географического районирования Донецко-Макеевская агломерация расположена в Донецкой возвышенной области Донецкой северо-степной провинции и граничит на востоке и юго-востоке с Шахтерским и Амвросиевским районами.

Старобешевский административный район граничит на севере с Донецком и на севе- 

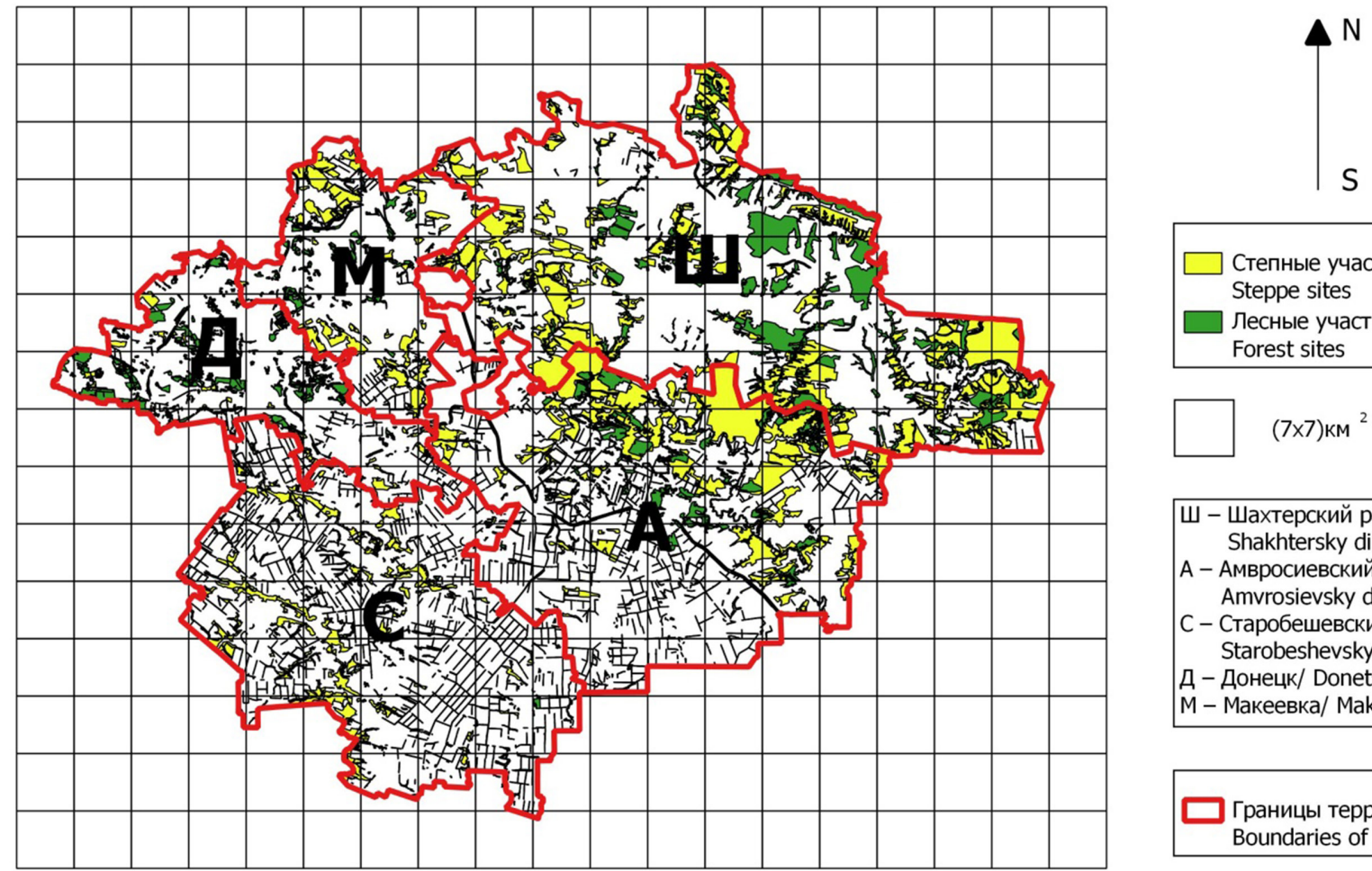

Степные участки/ Steppe sites

Лесные участки/ Forest sites

\section{$(7 \times 7)$ км $^{2}$}

Ш - Шахтерский район/ Shakhtersky district A - Амвросиевский район/ Amvrosievsky district C- Старобешевский район/ Starobeshevsky district Д - Донецк/ Donetsk M - Макеевка/ Makeevka

Puc. 1. Пространственная структура степных и лесных участков в административно-территориальных подразделениях Донецкой области

[Fig. 1. Spatial structure of steppe and forest sites in the administrative-territorial divisions (ATD) of the Donetsk region]

ро-востоке и востоке с Амвросиевским районом. На всей его территории абсолютно преобладает аграрный тип ландшафтов. Степень урбанизации очень низкая. Согласно физико-географическому районированию Старобешевский район практически полностью находится в Левобережно-Днепровско-Приазовской северостепной провинции в Приазовской возвышенной ее области и только юго-восточная его часть расположена в Приазовской низменной области вышеуказанной провинции [5].

Методом визуального выделения и машинного оконтуривания участков территории, определяемых по цвету и текстуре изображения на спутниковых космоснимках из свободного доступа спутника Sentinel-2A, с помощью компьютерной программы QGIS были выделены и статистически обработаны степные и лесные участки выше указанных районов и городов.

\section{ОБСУЖДЕНИЕ РЕЗУЛЬТАТОВ}

Пространственная структура выделенных нами степных и лесных участков исследованных районов и городов указана в виде обобщенной их картосхемы на рисунке 1 .

В таблице приведены результаты статистической обработки полученных атрибутивных дан- ных программы QGIS в виде количества, общей и средней площади выделенных участков, а также показатели фрагментированности территории исследованных административно-территориальных подразделений в отношении степных и лесных участков.

Для оценки пространственной структуры какой-либо территории (или ландшафта) помимо определения количества, общей и средней площади участков данного типа территорий, очень важны показатели их фрагментированности (то есть количественные их характеристики как отдельных фрагментов/частей всей исследуемой территории или ландшафта).

Наиболее информативными в этом плане являются показатели фрагментированности территорий, которые в контексте биологической интерпретации отражают степень их инсуляризации («островной эффект»).

Подобные исследования довольно широко отражены в научной литературе, в том числе относящейся и к региону Донбасса $[1,3,4,6,7,8,9,10$, $12,13,14,15,16,17]$.

Наиболее часто используются показатели когерентности $(\mathrm{C})$ и выводимый из нее «эффективный размер ячейки» $\left(\mathrm{m}_{\text {eff }}\right)$. 
Таблииа

Количественные показатели степных и лесных участков в составе административно-территориальных подразделений (АТП) Донецкой области

[Table. Quantitative indicators of steppe and forest sites as part of administrative-territorial divisions (ATD) in the Donetsk region]

\begin{tabular}{|c|c|c|c|c|c|c|c|}
\hline \multirow[b]{2}{*}{$\begin{array}{c}\text { Тип территории / Type of } \\
\text { territory }\end{array}$} & \multicolumn{7}{|c|}{ Количественные показатели / Quantitative indicators } \\
\hline & $\mathrm{N}$ & $\begin{array}{l}\mathrm{S}_{\text {об }}(\text { га) / в \% от } \\
\mathrm{S}_{\text {АTп }} / \mathrm{S}_{\mathrm{g}} \text { (ha) / in } \\
\% \text { of the } \mathrm{S}_{\text {АTD }}\end{array}$ & $\begin{array}{l}\mathrm{S}_{\mathrm{cp}}(\mathrm{ra}) / \\
\mathrm{S}_{\mathrm{m}}(\mathrm{ha})\end{array}$ & $\mathrm{C}$ & $\mathrm{m}_{\text {eff }}$ & $\begin{array}{l}\mathrm{m}_{\text {eff }} \\
/ \mathrm{S}_{\mathrm{m}}\end{array}$ & LDI \\
\hline 1 & 2 & 3 & 4 & 5 & 6 & 7 & 8 \\
\hline \multicolumn{8}{|c|}{ Шахтерский район / Shakhtersky district $(167185,085$ га / ha) } \\
\hline $\begin{array}{l}\text { 1. Все участки / All sites: } \\
\text { 1) степные / steppe } \\
\text { 2) лесные / forest }\end{array}$ & $\begin{array}{c}227 \\
1307\end{array}$ & $\begin{array}{l}34640,97 / 20,7 \\
23215,47 / 13,9\end{array}$ & $\begin{array}{c}152,60 \\
17,76\end{array}$ & $\begin{array}{l}0,00082 \\
0,00047\end{array}$ & $\begin{array}{c}136,81 \\
78,63\end{array}$ & $\begin{array}{l}0,90 \\
\mathbf{4 , 4 3}\end{array}$ & $\begin{array}{l}0,121 \\
0,286\end{array}$ \\
\hline $\begin{array}{l}\text { 2. Участки / Sites > 1 га / ha: } \\
\text { 1) степные / steppe } \\
\text { 2) лесные / forest }\end{array}$ & $\begin{array}{l}226 \\
925\end{array}$ & $\begin{array}{l}34640,97 / 20,7 \\
23033,23 / 13,8\end{array}$ & $\begin{array}{l}153,28 \\
24,90\end{array}$ & $\begin{array}{l}0,00082 \\
0,00047\end{array}$ & $\begin{array}{c}136,81 \\
78,64\end{array}$ & $\begin{array}{l}0,89 \\
\mathbf{3 , 1 6}\end{array}$ & $\begin{array}{l}0,121 \\
0,271\end{array}$ \\
\hline $\begin{array}{l}\text { 3. Участки / Sites > } 3 \text { га / ha: } \\
\text { 1) степные / steppe } \\
\text { 2) лесные / forest }\end{array}$ & $\begin{array}{l}224 \\
543 \\
\end{array}$ & $\begin{array}{l}34637,45 / 20,7 \\
22324,78 / 13,4 \\
\end{array}$ & $\begin{array}{c}154,63 \\
41,11 \\
\end{array}$ & $\begin{array}{l}0,00082 \\
0,00047 \\
\end{array}$ & $\begin{array}{c}136,81 \\
78,63\end{array}$ & $\begin{array}{l}0,88 \\
\mathbf{1 , 9 0}\end{array}$ & $\begin{array}{c}0,121 \\
0,23\end{array}$ \\
\hline \multicolumn{8}{|c|}{ Амвросиевский район / Amvrosievsky district (141823,68 га / ha) } \\
\hline $\begin{array}{l}\text { 1. Все участки / All sites: } \\
\text { 1) степные / steppe } \\
\text { 2) лесные / forest }\end{array}$ & $\begin{array}{c}100 \\
1048\end{array}$ & $\begin{array}{c}22385,24 / 15,8 \\
12020,18 / 8,5\end{array}$ & $\begin{array}{c}223,85 \\
11,47\end{array}$ & $\begin{array}{c}0,0014 \\
0,00008\end{array}$ & $\begin{array}{c}191,08 \\
10,75\end{array}$ & $\begin{array}{l}0,85 \\
0,94\end{array}$ & $\begin{array}{c}0,097 \\
0,44\end{array}$ \\
\hline $\begin{array}{l}\text { 2. Участки / Sites > 1 га / ha: } \\
\text { 1) степные / steppe } \\
\text { 2) лесные / forest }\end{array}$ & $\begin{array}{c}98 \\
844\end{array}$ & $\begin{array}{r}2238 \\
1191\end{array}$ & $\begin{array}{c}228,41 \\
14,11\end{array}$ & $\begin{array}{c}0,0013 \\
0,00008\end{array}$ & $\begin{array}{c}191,08 \\
10,74\end{array}$ & $\begin{array}{l}0,84 \\
0,76\end{array}$ & $\begin{array}{c}0,096 \\
0,43\end{array}$ \\
\hline $\begin{array}{l}>3 \text { га / ha: } \\
\text { pe } \\
\text { t }\end{array}$ & $\begin{array}{c}94 \\
517\end{array}$ & $\begin{array}{c}22377,51 / 15,8 \\
11271,95 / 7,9 \\
\end{array}$ & $\begin{array}{c}238,06 \\
21,80 \\
\end{array}$ & $\begin{array}{c}0,0013 \\
0,00008 \\
\end{array}$ & $\begin{array}{c}191,08 \\
10,74\end{array}$ & $\begin{array}{l}0,80 \\
0,49 \\
\end{array}$ & $\begin{array}{c}0,096 \\
0,38\end{array}$ \\
\hline \multicolumn{8}{|c|}{ г. Донецк / Donetsk City (55846,27 га / ha) } \\
\hline 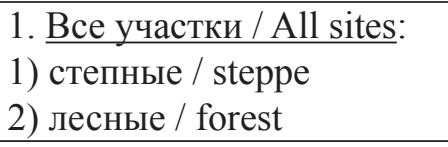 & $\begin{array}{c}51 \\
878\end{array}$ & $\begin{array}{r}167 \\
7046\end{array}$ & $\begin{array}{c}32,76 \\
8,03\end{array}$ & $\begin{array}{l}0,00006 \\
0,00017\end{array}$ & $\begin{array}{l}3,29 \\
9,72\end{array}$ & $\begin{array}{l}0,10 \\
1,21 \\
\end{array}$ & $\begin{array}{c}0,094 \\
0,42\end{array}$ \\
\hline $\begin{array}{l}\text { 2. Участки / Sites > 1 га / ha: } \\
\text { 1) степные / steppe } \\
\text { 2) лесные / forest }\end{array}$ & $\begin{array}{c}48 \\
625\end{array}$ & $\begin{array}{c}1669,60 / 3,0 \\
6921,60 / 12,4\end{array}$ & $\begin{array}{l}34,78 \\
11,07\end{array}$ & $\begin{array}{l}0,00006 \\
0,00017\end{array}$ & $\begin{array}{l}3,29 \\
9,72\end{array}$ & $\begin{array}{l}0,09 \\
0,88 \\
\end{array}$ & $\begin{array}{c}0,094 \\
0,39\end{array}$ \\
\hline $\begin{array}{l}\text { 3. Участки / Sites > } 3 \text { га / ha: } \\
\text { 1) степные / steppe } \\
\text { 2) лесные / forest }\end{array}$ & $\begin{array}{c}46 \\
358 \\
\end{array}$ & $\begin{array}{c}1665,37 / 3,0 \\
6441,21 / 11,5\end{array}$ & $\begin{array}{l}36,20 \\
17,99 \\
\end{array}$ & $\begin{array}{l}0,00006 \\
0,00017 \\
\end{array}$ & $\begin{array}{l}3,29 \\
9,70\end{array}$ & $\begin{array}{l}0,09 \\
0,54\end{array}$ & $\begin{array}{c}0,093 \\
0,32 \\
\end{array}$ \\
\hline \multicolumn{8}{|c|}{ г. Макеевка / Makeevka City (50878,9 га / ha) } \\
\hline $\begin{array}{l}\text { 1. Все участки/All sites: } \\
\text { 1) степные/ steppe } \\
\text { 2) лесные/ forest }\end{array}$ & $\begin{array}{c}77 \\
380 \\
\end{array}$ & $\begin{array}{c}6875,10 / 13,5 \\
3249,57 / 6,4 \\
\end{array}$ & $\begin{array}{c}89,29 \\
8,55\end{array}$ & $\begin{array}{l}0,00075 \\
0,00004\end{array}$ & $\begin{array}{c}37,91 \\
2,12 \\
\end{array}$ & $\begin{array}{l}0,43 \\
0,25 \\
\end{array}$ & $\begin{array}{c}0,122 \\
0,35\end{array}$ \\
\hline $\begin{array}{l}\text { 2. Участки/ Sites > } 1 \text { га / ha: } \\
\text { 1) степные / steppe } \\
\text { 2) лесные / forest }\end{array}$ & $\begin{array}{c}76 \\
308\end{array}$ & $\begin{array}{c}6874,21 / 13,5 \\
3207,91 / 6,3\end{array}$ & $\begin{array}{l}90,45 \\
10,42\end{array}$ & $\begin{array}{l}0,00075 \\
0,00004\end{array}$ & $\begin{array}{c}37,98 \\
2,12\end{array}$ & $\begin{array}{l}0,42 \\
0,20\end{array}$ & $\begin{array}{c}0,122 \\
0,34\end{array}$ \\
\hline $\begin{array}{l}\text { 3. Участки/ Sites > } 3 \text { га / ha: } \\
\text { 1) степные / steppe } \\
\text { 2) лесные / forest }\end{array}$ & $\begin{array}{c}72 \\
211\end{array}$ & $\begin{array}{c}6878,27 / 13,5 \\
3024,70 / 5,9\end{array}$ & $\begin{array}{l}95,39 \\
14,34\end{array}$ & $\begin{array}{l}0,00075 \\
0,00004 \\
\end{array}$ & $\begin{array}{c}37,98 \\
2,12\end{array}$ & $\begin{array}{l}0,40 \\
0,15\end{array}$ & $\begin{array}{c}0,121 \\
0,30\end{array}$ \\
\hline
\end{tabular}




\begin{tabular}{|c|c|c|c|c|c|c|c|}
\hline \multicolumn{8}{|c|}{ Донецк-Макеевка (общие для городов) / Donetsk-Makeevka (general for cities) } \\
\hline $\begin{array}{l}\text { 1. Все участки / All sites: } \\
\text { 1) степные / steppe }\end{array}$ & - & 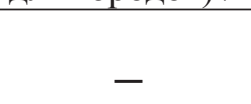 & - & - & - & - & - \\
\hline / forest & 8 & 58,91 & 7,36 & - & - & - & - \\
\hline \multicolumn{8}{|c|}{ Донецк + Макеевка / Donetsk+Makeevka (106725,17 га / ha) } \\
\hline $\begin{array}{l}\text { 1. Все участки / All sites: } \\
\text { 1) степные / steppe } \\
\text { 2) лесные / forest }\end{array}$ & $\begin{array}{c}128 \\
1266\end{array}$ & $\begin{array}{l}8545 \\
1035\end{array}$ & $\begin{array}{c}66,77 \\
8,18\end{array}$ & $\begin{array}{l}0,00019 \\
0,00006\end{array}$ & $\begin{array}{c}19,83 \\
6,11\end{array}$ & $\begin{array}{l}0,30 \\
0,75\end{array}$ & $\begin{array}{l}0,106 \\
0,391\end{array}$ \\
\hline $\begin{array}{l}\text { 2. Участки / Sites > 1 га / ha: } \\
\text { 1) степные / steppe } \\
\text { 2) лесные / forest }\end{array}$ & $\begin{array}{l}124 \\
941\end{array}$ & $\begin{array}{c}8543,81 / 8,0 \\
10188,42 / 9,6\end{array}$ & $\begin{array}{l}68,90 \\
10,83\end{array}$ & $\begin{array}{l}0,00019 \\
0,00006\end{array}$ & $\begin{array}{c}19,83 \\
6,10\end{array}$ & 0,29 & $\begin{array}{l}0,105 \\
0,368\end{array}$ \\
\hline $\begin{array}{l}\text { 3. Участки / Sites > } 3 \text { га / ha: } \\
\text { 1) степные / steppe } \\
\text { 2) лесные / forest }\end{array}$ & $\begin{array}{l}118 \\
574\end{array}$ & $\begin{array}{l}8533,64 / 8,0 \\
9517,75 / 8,9\end{array}$ & $\begin{array}{l}72,32 \\
16,58\end{array}$ & $\begin{array}{l}0,00019 \\
0,00006\end{array}$ & $\begin{array}{c}19,83 \\
6,09\end{array}$ & $\begin{array}{l}0,27 \\
0,37\end{array}$ & $\begin{array}{l}0,105 \\
0,311\end{array}$ \\
\hline \multicolumn{8}{|c|}{ Старобешевский район / Starobeshevsky district (125304,72 га / ha) } \\
\hline $\begin{array}{l}\text { 1. Все участки / All sites: } \\
\text { 1) степные / steppe } \\
\text { 2) лесные / forest }\end{array}$ & $\begin{array}{c}338 \\
1828\end{array}$ & $\begin{array}{l}9759,84 / 7,8 \\
3489,77 / 2,8 \\
\end{array}$ & $\begin{array}{c}28,88 \\
1,91\end{array}$ & $\begin{array}{c}0,00009 \\
0,000015\end{array}$ & $\begin{array}{c}10,93 \\
0,19\end{array}$ & $\begin{array}{l}0,38 \\
0,10\end{array}$ & $\begin{array}{l}0,181 \\
0,708\end{array}$ \\
\hline $\begin{array}{l}\text { 2. Участки / Sites > 1 га / ha: } \\
\text { 1) степные / steppe } \\
\text { 2) лесные / forest }\end{array}$ & $\begin{array}{l}303 \\
944\end{array}$ & $\begin{array}{l}9739,13 / 7,8 \\
3102,71 / 2,5\end{array}$ & $\begin{array}{c}32,14 \\
3,29\end{array}$ & $\begin{array}{c}0,00009 \\
0,0000015\end{array}$ & $\begin{array}{c}10,93 \\
0,19\end{array}$ & $\begin{array}{l}0,34 \\
0,06\end{array}$ & $\begin{array}{l}0,178 \\
0,623\end{array}$ \\
\hline $\begin{array}{l}\text { 3. Участки / Sites > } 3 \text { га / ha: } \\
\text { 1) степные / steppe } \\
\text { 2) лесные / forest }\end{array}$ & $\begin{array}{l}246 \\
313\end{array}$ & $\begin{array}{l}9630,56 / 7,7 \\
1970,92 / 1,6\end{array}$ & $\begin{array}{c}39,15 \\
6,30\end{array}$ & $\begin{array}{c}0,00009 \\
0,0000014\end{array}$ & $\begin{array}{l}10,93 \\
0,174\end{array}$ & $\begin{array}{l}0,28 \\
0,03\end{array}$ & $\begin{array}{l}0,170 \\
0,425\end{array}$ \\
\hline
\end{tabular}

Примечания: $\mathrm{N}$ - количество участков; $\mathrm{S}_{\text {об }}$ общая площадь участков; $\mathrm{S}_{\mathrm{cp}}$ - средняя площадь участков; $\mathrm{C}$ - когерентность; $\mathrm{m}_{\text {eff }}-$ эффективный размер ячейки; LDI - индекс изрезанности ландшафта (пояснения в тексте).

[Notes: $\mathrm{N}$ - number of sites; $\mathrm{S}_{\mathrm{ob}}$ - total area of plots; $\mathrm{S}_{\mathrm{cp}}$ - average area of plots; $\mathrm{C}$ - coherence; $\mathrm{m}_{\text {eff }}$ - effective cell size; LDI landscape ruggedness index (see text for explanations)].

Когерентность (С) показывает вероятность нахождения двух произвольно выбранных точек в пределах одного фрагмента территории. Определяется по формуле:

$$
C=\sum_{i=1}^{n}\left(\frac{F_{i}}{F_{g}}\right)^{2},
$$

где $\mathrm{C}$ - показатель когерентности, $\mathrm{F}_{\mathrm{i}}$ - площадь і-того фрагмента, Fg - площадь всей исследуемой территории, $\mathrm{n}$ - общее число фрагментов.

Эффективный размер ячейки $\left(\mathrm{m}_{\text {eff }}-\right.$ effective mesh size) - это площадь, которая будет получена, если всю исследуемую территорию разделить на одинаковые фрагменты, сохранив при этом существующую когерентность $[8,11]$ :

$$
m_{e f f}=\mathrm{Fg} \cdot \mathrm{C}
$$

Биологическая интерпретация в отношении когерентности говорит о вероятности встречи двух животных (одного вида) в пределах исследуемой территории, не встречая непреодолимых для себя препятствий (т.е. границ фрагмента, которую они не могут преодолеть). Эффективный размер ячейки, в данном аспекте, показывает условную площадь данного типа фрагмента (типа природной территории) при существующем уровне фрагментации всей исследуемой территории, на которой животное может свободно перемещаться, не встречая непреодолимых препятствий на своем пути [3]. В отличие от когерентности, $\mathrm{m}_{\text {eff }}$ измеряется в тех же размерных единицах, что и площади самих фрагментов (га или км²), поэтому интерпретация эффективного размера ячейки позволяет сравнивать его значение, например, со средней площадью данного типа фрагмента на исследуемой территории.

О характере фрагментированности природных территорий можно судить также и по индексу изрезанности ландшафта - LDI (landscape dissection index), который выражает внедрение 
фрагментирующей сети в ландшафт без полного его рассечения $[6,11,13]$. Рассчитывается он по формуле:

$$
L D I=\frac{\sum_{i=1}^{n} P_{i}}{\sqrt[2]{\pi \cdot F g \cdot \sum_{i=1}^{n} F_{i}}},
$$

где $\mathrm{P}_{\mathrm{i}}$ - периметр i-того фрагмента (км), $\mathrm{F}_{\mathrm{i}}-$ площадь і-того фрагмента $\left(\right.$ км² $\left.^{2}\right), \mathrm{Fg}$ - площадь всей исследуемой территории $\left(\mathrm{\kappa m}^{2}\right)$.

В отличие от $\mathrm{m}_{\text {eff }}$ данный показатель не зависит от когерентности.

Все указанные количественные характеристики показаны в трех вариантах: 1) для всех выделенных участков в пределах АТП; 2) для участков этих же типов территорий площадью более 1 га; 3 ) для участков площадью более 3 га. Это сделано для того, чтобы понять, существенно ли меняются показатели фрагментированности территории с изменением числа выделяемых участков (фрагментов) и исключением самых мелких (соответственно $<$ га и $<3$ га).

Как видно из данных таблицы, ни значения когерентности, ни $\mathrm{m}_{\text {eff }}$ и LDI практически не меняются при последовательном отсечении из общей выборки участков площадью $<1$ га и $<3$ га. Это говорит о том, что эти показатели зависят именно от характера их фрагментации в общей структуре ландшафта, а не от их количества и занимаемой площади. Из этого можно сделать важный вывод о том, что при общей оценке пространственной структуры какой-либо достаточно обширной территории (или ландшафта) достаточно ограничиться участками площадью не менее 3 га. Более мелкие участки не играют заметной роли ни как средообразующие элементы экологического каркаca, ни как значимые рефугиумы для большинства биологических видов.

Кроме всех выше указанных показателей, мы ввели еще один, на наш взгляд весьма информативный количественный признак, отражающий характер пространственной структуры всей территории, а именно: отношение эффективного размера ячейки данного типа участка к средней его площади: $\mathbf{m}_{\text {eff }} / \mathbf{S}_{\mathbf{c p}}$.

Необходимость введения этого показателя, на наш взгляд, продиктовано тем, что он отражает характер «пространственного доминирования» участков определенного размерного класса в общей структуре всей территории или ландшафта. Так, например, для лесных участков в Шахтерском районе показатель $\mathbf{m}_{\text {eff }} / \mathbf{S}_{\mathrm{cp}}$ существенно больше 1,0 при всех трех вариантах их выборки (в таблице выделено жирным шрифтом). В то время как для степных участков этот показатель чуть меньше единицы. Это говорит о том, что в Шахтерском районе при подавляющем большинстве мелких по площади лесных участков имеется небольшое число очень крупных по площади, заметно превышающей их «фоновые», то есть средние значения. Размерное распределение степных участков в Шахтерском районе имеет более равномерный, сглаженный характер и поэтому соотношение $\mathbf{m}_{\text {eff }} / \mathbf{S}_{\mathbf{c p}}$ здесь близко к единице. Тоже самое можно сказать и о степных и лесных участках в Амвросиевском районе. Иначе говоря, когда средняя площадь и эффективный размер ячейки данного типа природной территории (участков) близки между собой, то есть их отношения близки к единице, то можно говорить о «нормальном» фоновом их распределении.

Напротив, когда отношение $\mathbf{m}_{\text {eff }} / \mathbf{S}_{\mathrm{cp}}$ много меньше единицы, в нашем случае для степных участков города Донецка и лесных участков Старобешевского района, можно утверждать, что в пространственной их структуре абсолютно преобладают очень мелкие по площади, преимущественно линейной конфигурации, и полностью отсутствуют крупноразмерные.

Сравнивая между собой административно-территориальные подразделения по составу распространения степных и лесных участков, то степные в порядке убывания их общих площадей (в га) выстраиваются в следующей последовательности: 1) Шахтерский район $(34640,97) ; 2)$ Амвросиевский район $(22385,24) ; 3)$ Старобешевский район $(9759,84)$; 4) Донецк+Макеевка $(8545,93)$; 5) Макеевка $(6875,10) ; 6)$ Донецк $(1670,82)$.

В относительной доле степных участков к площади всего АТП (в \%) эта последовательность выглядит следующим образом: 1) Шахтерский район $(20,7) ; 2)$ Амвросиевский район $(15,8) ; 3)$ Макеевка $(13,5)$; 4) Донецк+Макеевка $(8,0) ; 5)$ Старобешевский район $(7,8) ; 6)$ Донецк $(3,0)$.

По общим площадям (га) лесных участков убывающий ряд АТП выглядит так: Шахтерский район $(23215,47)$ - Амвросиевский район $(12020,18)$ -Донецк+Макеевка $(10413,51)$ - Донецк $(7046,12)$ - Старобешевский район $(3489,77)$ - Макеевка $(3249,57)$.

По относительной доле (в \%) лесных участков этот ряд выглядит следующим образом: Шахтерский район $(13,9)$ - Донецк $(12,6)$-Донецк+Макеевка $(9,8)$ - Амвросиевский район $(8,5)$ - Макеевка $(6,4)$-Старобешевский район $(2,8)$. 
Видно, что по всем двум типам природных территорий - степных и лесных участков абсолютным рекордсменом является Шахтерский район, как по общим значениям их площадей, так и по их относительной доле. Причем доля степных участков в Шахтерском районе в полтора раза превышает долю лесных. На втором месте находится Амвросиевский район, в котором доля степных участков почти в два раза превышает лесные. Третье место по общей площади степных участков занимает Старобешевский район, в котором их относительная часть в 2,8 раза превышает долю лесных участков. По общей площади лесных участков Старобешевский район находится на пятом месте, уступая по этому показателю также Донецко-Макеевкской агломерации и Донецку. По относительной доле лесных участков Старбешевский район находится на последнем шестом месте, являясь самым нелесистым среди исследованных АТП.

Практически по всем АТП имеет место существенное превышение площади степных участков над лесными, за исключением города Донецка, где лесные комплексы (парки, скверы) более чем в четыре раза превышают степные.

В Макеевке по сравнению с Донецком гораздо меньше парков и скверов. Среди зеленных массивов преобладают лесопосадки на периферии города. Двукратное преобладание степных участков над лесными в Макеевке обусловлено тем, что в административных границах города очень велика доля ландшафтов аграрного типа, особенно в северной, восточной и юго-восточной его частях.

В общей сумме природных территорий (степные и лесные участки) по общим их площадям (га) в порядке убывания исследованные АТП выстраиваются в следующий ряд: Шахтерский район $(57856,47)$-Амвросиевский район $(34405,42)$ - Донецк+Макеевка $(18959,44)$-Старобешевскй район $(13249,61)$ - Макеевка $(10124,67)$ - Донецк $(8716,94)$.

По относительной их доле к площади АТП (в \%) этот ряд имеет вид: Шахтерский район $(34,6)$ - Амвросиевский район $(24,3)$ - Макеевка $(19,9)$ - Донецк +Макеевка $(17,8)$ - Донецк $(15,6)$ - Старобешевский район $(10,57)$.

Таким образом, средний показатель относительной доли основных типов природных территорий региона (степных и лесопокрытых участков) для всех обследованных АТП составляет $21 \%$. Учитывая, что в составе выделенных нами «природных участков» существенная доля приходится на антропогенные территории, то можно считать состояние экологического каркаса неудовлетворительным. Необходимо принимать срочные меры по его оптимизации в виде официального перевода всех его компонентов в соответствующий статус региональной экологической сети.

Характер распределения (в \%) природных участков в исследованных АТП по диапазону занимаемых площадей показан на рисунке 2 . В каждом АТП все степные и лесные участки (>3 га) были распределены на группы в размерном диапазоне: 0-100 га; 100-300 га; 300-500 га; 500-1000 га и $>1000$ га.

По степным участкам во всех АТП большинство участков находятся в первом размерном класce (0-100 га). Однако дальнейшее их изменение в последующих размерных классах существенно различно в разных АТП. Достаточно выравненный характер имеет уменьшение их количества по мере возрастания размерного диапазона только в двух районах - Шахтерском и Амвросиевском.

Причем в Шахтерском районе уменьшение количества степных участков по их размерам имеет гораздо более резкий вид - уменьшается от полутора до более чем трех раз. В Амвросиевском районе уменьшение гораздо более сглажено - при переходе в более крупный размерный класс количество участков снижается примерно в два раза.

В Макеевке уменьшение количества степных участков имеет еще более резкий характер - от двух до четырех с лишним раза. В границах города и его окрестностей вообще отсутствуют степные участки площадью более 1000 га.

И, наконец, в Донецке и Старобешевском районе крупных степных участков практически нет. В Старобешевском районе только три участка (1,2 \%) имеют площадь 300-500 га, в Донецке нет вообще степных участков площадью более 300 га. Абсолютное большинство степных участков (более 90 \%) в Донецке и Старобешевском районе находятся в самом малом размерном классе 0-100 га.

По лесным участкам абсолютное их большинство (более 90 \%) во всех АТП находятся в первом размерном классе 0-100 га. Только в Шахтерском районе имеются лесные участки площадью более 500 (четыре участка) и более 1000 га (три участка). Относительно крупные лесные участки (300-500 га) имеются также в Амвросиевском районе и в Донецке (три и два соответственно). В Макеевке только один процент лесопокрытых участков (два участка) находятся в размерном диапазоне 100-300 га. 


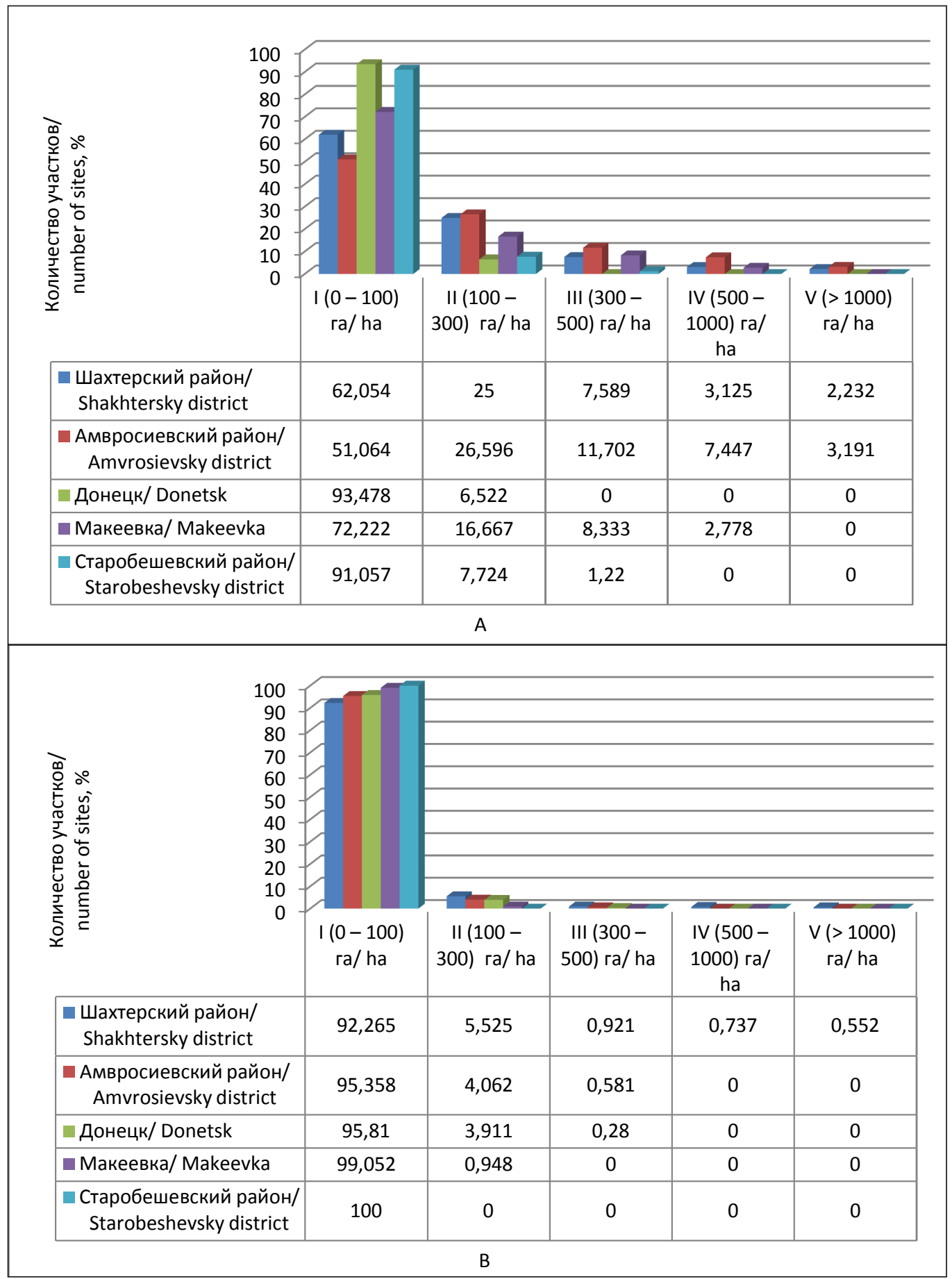

Puc. 2. Количественное распределение (в \%) степных (А) и лесных (В) участков в АТП по диапазону занимаемых площадей

[Fig. 2. Quantitative distribution (in \%) of steppe (A) and forest (B) sites in the ATD by the range of occupied areas]

В Старобешевском районе все $100 \%$ лесных участков находятся в самом малом размерном классе 0-100 га. Практически можно говорить об абсолютно полном безлесии Старобешевского района.

\section{ЗАКЛЮЧЕНИЕ}

Проведенные нами исследования являются первой попыткой сравнительного анализа структуры экологического каркаса территории надрай- онного уровня в Донецком регионе, проведенного с использованием космоснимков и методов ГИС-технологий. Также эти исследования можно считать начальным этапом инвентаризации природных и полуприродных территорий Донбасса с целью дальнейшей их пространственной и правовой оптимизации в соответствующую структуру региональной экологической сети, на основе ко- 
торой реализовывалось бы устойчивое неистощительное природопользование и сохранялось природное разнообразие этого региона.

Оценка пространственной структуры экологического каркаса центральной части территории Донбасса в виде количественного анализа распределения в нем двух основных типов природных территорий - степных и лесных участков позволяет нам сделать следующие выводы.

1. Во всех исследованных АТП, кроме города Донецка, степные участки по занимаемой площади существенно превышают лесные, что свидетельствует о преимущественно степном характере ландшафта в центральной части Донбасса в целом.

2. Как степные, так и лесные участки во всех исследованных АТП имеют высокую степень фрагментации. Учитывая, что эти два основных типа природных территорий занимают в среднем только $21 \%$ территории АТП, следует считать пространственную структуру экологического каркаса в регионе неудовлетворительной.

3. Из обследованных АТП только Шахтерский и Амвросиевский районы имеют относительно высокую долю природных территорий в своем составе (соответственно 34,6 \% и 24,3\% от их площадей). Это обусловлено тем, что значительная часть их территории расположена на отрогах Донецкого кряжа с его сложной холмисто-грядовой структурой рельефа, обуславливающей высокое природное разнообразие данной части региона и, как следствие, хороший уровень его сохранности.

4. Характер распределения природных участков по диапазону занимаемых площадей показал, что по степным участкам уменьшение их количества с возрастанием площади имеет более выравненный характер по сравнению с лесными участками, особенно в Шахтерском и Амвросиевском районах. Тем не менее, во всех АТП большая часть степных участков находится в самом нижнем размерном классе диапазона площадей - 0-100 га. По лесным участкам количественный перепад с увеличением размерного диапазона гораздо более резкий. Абсолютное большинство лесных участков (более 90 \%) во всех АТП находится в самом нижнем размерном классе.

5. Введенный нами показатель $\mathbf{m}_{\text {eff }} / \mathbf{S}_{\mathbf{c p}}$ отражает характер «пространственного доминирования» участков в ландшафте: когда он существенно больше единицы, как в нашем случае для лесных участков в Шахтерском районе, это свидетель- ствует о наличии нескольких очень крупных по площади участков на общем фоне малоразмерного их количества. И наоборот, когда этот показатель значительно меньше единицы, например, для степных участков в Донецке и лесных участков в Старобешевском районе, это говорит об абсолютном преобладании в их пространственной структуре малоразмерных участков и/или участков вытянутой линейной конфигурации (лесополос). В первом случае показатель $\mathbf{m}_{\text {eff }} / \mathbf{S}_{\mathbf{c p}}$ может быть своего рода индикатором наличия крупных природных ядер, которым следует присваивать статус ООПТ.

6. В целом анализ пространственной структуры экологического каркаса в исследованных АТП показывает, что наиболее негативно на его разнообразие влияет аграрное использование ландшафта, а не степень урбанизации. А наиболее положительным фактором сохранения природного разнообразия является сложность структуры рельефа территории.

\section{СПИСОК ЛИТЕРАТУРЫ}

1. Биатов А.П., Украинский П.А., Нарожняя А.Г. Сравнительный анализ фрагментированности ландшафтов Белгородской части бассейна Ворсклы и бассейна Мерлы (Харьковская область, Украина) // Научные ведомости Белгородского государственного университета. Серия: Естественные науки, 2014, вып. 26, № 3 (174), с. 157-165.

2. Блакберн А.А, Золотой А.Л. Количественная оценка состава природных территорий (степных и лесных участков) Шахтерского района Донецкой Народной Республики // Научные ведомости Белгородского государственного университета. Серия: Естественные науки, 2019, вып. 43, № 3, с 276-285. DOI: https:// doi.org/10.18413/2075-4671-2019-43-3-276-285

3.ЗахаровК. В.Оценкастепенифрагментацииместообитаний диких животных искусственными рубежами на примере Московского региона // Бюллетень МОИП. Отдел биологический, 2015, т. 120, вып. 2, с. 3-10.

4. Клюев В.Е., Аверин Г.В. Оценка фрагментации экологической сети Луганской области // Системный анализ и информационные технологии в науках о природе и обществе, 2014, № 1 (6)-2 (7), с. 84-90.

5. Маринич О.М, Шищенко П.Г. Фізична географія Украӥни: Підручник. Київ: Т-во «Знання», КОО, 2006. $511 \mathrm{c}$.

6. Украинский П. А. Изучение фрагментации ландшафтов Белгородской части бассейна Ворсклы при помощи ГИС и ДДЗ // Материаль научно-практической конференции «Геоинформационные науки и экологическое развитие: новые подходы, методы, технологии. Геоинформационные технологии и космический мониторинг». Ростов-на-Дону, 2013, т.2, с. 196-201.

7. Усова И.П. Оценка фрагментации лесов с использованием ландшафтных индексов (на примере 
Восточно-Белорусской ландшафтной провинции) // Материаль III Всероссийской иколь-конференичи. II часть «Актуальные проблемы геоботаники». Петрозаводск, 2007, с. 250-253.

8. Чепелев О.А., Украинский П.А., Соловьев В.И. и др. Использование данных многозональной космической съемки для анализа свойств почвы и растительности в условиях европейской лесостепи // Вестник Воронежского государственного университета. Серия: География. Геоэкология, 2009, № 1, с. 55-60.

9. Esswein H., Jaeger J., Schwarz von Raumer H.-G. Der Grad der Landschafts zerschneidung als Indikatorim Naturschutz: Unzerschnittene verkehrsarme (UZR) // Räume oder effective Maschenweite (meff) NNA Berichte, 2003, no 16, pp. 53-68.

10. Esswein H., Schwarz von Raumer H.-G. Effektive Maschenweite und Unzer schnittene Verkehrsarme Räume über $100 \mathrm{~km}^{2}$ als Umwelt indikatoren für die BRD GIS-Einsatz und vergleichende Analyse // Angewandte Geoinformatik, 2006, pp. 135-144.

11. Jaeger J. Landscape division, splitting index, and effective mesh size: new measures of landscape fragmentation // Landscape Ecology, 2000, no 15, pp. 115130. DOI: https://doi.org/10.1023/A:1008129329289

12. Jaeger J., Bertiller R., Schwick C. Degree of landscape fragmentation in Switzerland: Quantitative analysis 1885-2002 and implications for traffic planning and regional planning. Condensed Version. Neuchâtel, Bundesamt für Statistik, 2007. 36 p.

13. Jaeger J., Soukup T., Madriñán L.F. Landscape fragmentation in Europe (EEA-FOEN report. EEA Report 2). Luxembourg, Federal Office for the Environment FOEN, European Environment Agency EEA, 2011. 87 p.

14. Hargis C. D., Bissonette J. A. David J. L. The behavior of landscape metrics commonly used in the study of habitat fragmentation // Landscape Ecology, 1998, no 13, pp.167-186. DOI: https://doi. org/10.1023/A:1007965018633

15. Harris L. D. The Fragmented Forest: Island Biogeography Theory and the Presevation of Biotic Diversity. Chicago: University of Chicago Press, 1984. 211 p.

16. Schupp D. Umwelt indicator Landschafts zerschneidung: Ein zentrales Element zur Verknüpfung von Wissenschaft und Politik // GAIA, 2005, vol. 14 (2), pp. 101-106. DOI: https://doi.org/10.14512/gaia.14.2.8

17.Walz U. Landscape Structure, Landscape Metrics and Biodiversity // Living Reviews in Landscape Research, 2011, vol. 5 (3), pp. 1-35. DOI: https://doi.org/10.12942/ 1rlr-2011-3

Конфликт интересов: Авторы декларируют отсутствие явных и потенциальных конфликтов интересов, связанных с публикацией настоящей статьи.

Поступила в редакцию 07.04.2020

Принята к публикаџии 02.03.2021

\title{
Quantitative Analysis of the Structure of Forest and Steppe Areas in the Donetsk Region
}

\author{
A.A. Blackburn ${ }^{\infty}$, V. M. Ostapko, A. L. Zolotoi \\ Donetsk Botanical Garden, Ukraine \\ (110, Ilyich Ave., Donetsk, 83059)
}

\begin{abstract}
The purpose of the study is a preliminary inventory and comparative quantitative assessment of natural sites of a number of the administrative-territorial divisions (ATD) in the Donetsk region.

Objects and methods: using the method of visualizing space images from the free access of the Sentinel-2A satellite and the QGIS computer program, the number, areas, fragmentation indicators of two main types of natural (quasi-natural) ecosystems of the region were determined - steppe and forest-covered territories within the boundaries of three districts (Shakhtersky, Amvrosievsky, Starobeshevsky) and Donetsk-Makeevska agglomeration.

Results: it was shown that, despite the quantitative predominance of forested sites over steppe areas, the latter significantly exceed the former in terms of occupied areas, which indicates the steppe nature of the landscape as a whole. Both steppe and forested areas have a high degree of fragmentation, which does not depend
\end{abstract}

(C) Blackburn A. A., Ostapko V. M., Zolotoi A. L., 2021

$\triangle$ Andrei A. Blackburn, e-mail: blackburn.fox@mail.ru

The content is available under Creative Commons Attribution 4.0 License. 
on the lower limit of the area of an individual site (all considered sites, sites with an area of more than 1 ha and sites with an area of more than $3 \mathrm{ha}$ ). In the aggregate of both types of natural territories, the Shakhtersky district is the richest in them. Amvrosiyevsky district follows it (both are located in the eastern part of the Donetsk region). The Donetsk-Makeevka agglomeration is in third place and the Starobeshevsky district is in last place. In general, all natural (quasi-natural) territories of the studied ATD occupy $21 \%$ of their area, which indicates a low level of preservation of the ecological framework in this part of the Donbass. The analysis of the spatial structure of the ecological framework in the studied ATD showed that the agrarian use of the landscape rather than the degree of urbanization influences its diversity most negatively. And the most positive factor in the conservation of natural diversity is the complexity of the relief structure of the territory.

Key words: ecological framework, ecological network, steppe and forest-covered territories, indicators of territory fragmentation, satellite images, QGIS.

For citation: Blackburn A.A., Ostapko V. M., Zolotoi A. L. Quantitative Analysis of the Structure of Forest and Steppe Areas in the Donetsk Region. Vestnik Voronezskogo gosudarstvennogo universiteta. Seria: Geografia. Geoekologia, 2021, no. 1, pp. 25-36. (In Russ.) DOI: https://doi.org/10.17308/geo.2021.1/3253

\section{REFERENCES}

1. Biatov A.P., Ukrainskiy P.A., Narozhnyaya A.G. Sravnitel'nyy analiz fragmentirovannosti landshaftov Belgorodskoy chasti basseynaVorsklyi basseyna Merly (Khar'kovskaya oblast', Ukraina) [Comparative analysis of landscape fragmentation in the Vorskla and the Merla river basins (Kharkov region, Ukraine)]. Nauchnye vedomosti Belgorodskogo gosudarstvennogo universiteta. Seria: Estestvennye nauki, 2014, v. 26, no 3 (174), pp. 157-165. (In Russ.)

2. Blakbern A.A, Zolotoy A.L. Kolichestvennaya otsenka sostava prirodnykh territoriy (stepnykh i lesnykh uchastkov) Shakhterskogo rayona Donetskoy Narodnoy Respubliki [Quantitative Estimation of the Composition of Natural Territories (Steppe and Forest Sites) of the Shakhtersk District of Donetsk People's Republic]. Nauchnye vedomosti Belgorodskogo gosudarstvennogo universiteta. Seria: Estestvennye nauki, 2019, v. 43, no 3, pp. 276-285. (In Russ.) DOI: https://doi.org/10.18413/2075-4671-201943-3-276-285.

3. Zakharov K.V. Otsenka stepeni fragmentatsii mestoobitaniy dikikh zhivotnykh iskusstvennymi rubezhami na primere Moskovskogo regiona [Landscape fragmentation in the Moscow region]. Byulleten' MOIP. Otdel biologicheskiy, 2015, v. 120, no 2, pp. 3-10. (In Russ.)

4. Klyuev V.E., Averin G.V. Otsenka fragmentatsii ekologicheskoy seti Luganskoy oblasti. [Evaluation the fragmentation of ecological network of Luhansk region]. Sistemnyy analiz i informatsionnye tekhnologii $v$ naukakh o prirode $i$ obshchestve, 2014, no 1 (6)-2 (7), pp. 84-90. (In Russ.)

5. Marinich O.M, Shishchenko P.G. Fizichna geografiya Ukraïni: Pidruchnik [Physical Geography of Ukraine: textbook]. Kiev: T-vo «Znannya», KOO, 2006. 511 p. (In Ukr.)

6. Ukrainskiy P. A. Izuchenie fragmentatsii landshaftov Belgorodskoy chasti basseyna Vorskly pri pomoshchi GIS i DDZ [The study of landscape fragmentation of the basin of Vorskla in the Belgorod region using GIS and remote sensing data]. Materialy Mezhdunarodnoy konferentsii «Geoinformatsionnye nauki i ekologicheskoe razvitie: novye podkhody, metody, tekhnologii. Geoinformatsionnye tekhnologii i kosmicheskiy monitoring». Rostov-on-don, 2013, vol. 2, pp. 196-201. (In Russ.)

7. Usova I.P. Otsenka fragmentatsii lesov s ispol'zovaniem landshaftnykh indeksov (na primereVostochno-Belorusskoy landshaftnoy provintsii) [Assessment of forest fragmentation using landscape indices (on example the Eastern Belarusian landscape area)]. Materialy III Vserossiyskoy shkoly-konferentsii. II chast «Aktualnye problem geobotaniki». Petrozavodsk, 2007, pp. 250-253. (In Russ.)

8. Chepelev O.A., Ukrainskiy P.A., Solov'ev V.I. i dr. Ispol'zovanie dannykh mnogozonal'noy kosmicheskoy s"emki dlya analiza svoystv pochvy i rastitel'nosti v usloviyakh evropeyskoy lesostepi [Use of polyzonal space shooting data for the analysis of soil and vegetation characteristics within the european partially wooded steppe]. Vestnik Voronezskogo gosudarstvennogo universiteta. Seria: Geografia. Geoekologia, 2009, no 1, pp. 55-60. (In Russ.)

9. Esswein H., Jaeger J., Schwarz von Raumer H.G. Der Grad der Landschafts zerschneidung als Indikatorim Naturschutz: Unzerschnittene verkehrsarme (UZR). Räume oder effective Maschenweite (meff) NNA Berichte, 2003, no 16, pp. 53-68.

10. Esswein H., Schwarz von Raumer H.-G. Effektive Maschenweite und Unzer schnittene Verkehrsarme Räume über $100 \mathrm{~km}^{2}$ als Umwelt indikatoren für die BRD - GIS-Einsatz und vergleichende Analyse. Angewandte Geoinformatik, 2006, pp. 135-144.

11. Jaeger J. Landscape division, splitting index, and effective mesh size: new measures of landscape fragmentation. Landscape Ecology, 2000, no 15, pp. 115-130. DOI: https://doi.org/10.1023/A:1008129329289

12. Jaeger J., Bertiller R., Schwick C. Degree of landscape fragmentation in Switzerland: Quantitative analysis 1885-2002 and implications for traffic planning and regional planning. Condensed Version. Neuchâtel, Bundesamt für Statistik, 2007. 36 p.

13. Jaeger J., Soukup T., Madriñán L.F. Landscape fragmentation in Europe (EEA-FOEN report. EEA Report 2). Luxembourg, Federal Office for the Environment FOEN, European Environment Agency EEA, 2011. 87 p. 
14. Hargis C. D., Bissonette J. A. David J. L. The behavior of landscape metrics commonly used in the study of habitat fragmentation. Landscape Ecology, 1998, no 13, pp.167186. DOI: https://doi.org/10.1023/A:1007965018633

15. Harris L. D. The Fragmented Forest: Island Biogeography Theory and the Presevation of Biotic Diversity. Chicago: University of Chicago Press, 1984. 211 p.

16. Schupp D. Umwelt indicator Landschafts zerschneidung: Ein zentrales Element zur Verknüpfung von Wissenschaft und Politik. GAIA, 2005, vol. 14 (2), pp. 101106. DOI: https://doi.org/10.14512/gaia.14.2.8

\section{Блакберн Андрей Альфредович}

кандидат биологических наук, доцент, старший научный сотрудник отдела природной флоры и заповедного дела Донецкого ботанического сада, г. Донецк, Украина, ORCID: 0000-0003-1105-1877, e-mail: blackburn.fox@mail.ru

Остапко Владимир Михайлович

доктор биологических наук, профессор, заведующий отделом природной флоры и заповедного дела Донецкого ботанического сада, г. Донецк, Украина, e-mail:_ostapko.dbs@mail.ru

Золотой Андрей Леонидович

аспирант отдела природной флоры и заповедного дела Донецкого ботанического сада, г. Донецк, Украина, e-mail: andreyzolotoy08@mail.ru
17.Walz U. Landscape Structure, Landscape Metrics and Biodiversity. Living Reviews in Landscape Research, 2011, vol. 5 (3), pp. 1-35. DOI: https://doi.org/10.12942/ 1rlr-2011-3

Conflict of interests: The authors declare no information of obvious and potential conflicts of interest related to the publication of this article.

Received 07.04.2020 Accepted 02.03.2021

Andrei A. Blackburn

Cand. Sci. (Biol.), Associate Professor, Senior Researcher of the Department of Natural Flora and Conservation of the Donetsk Botanical Garden, Donetsk, Ukraine, ORCID: 0000-0003-1105-1877, e-mail: blackburn.fox@ mail.ru

Vladimir M. Ostapko

Dr. Sci. (Biol.), Professor, Head of the Department of Natural Flora and Conservation of the Donetsk Botanical Garden, Donetsk, Ukraine, e-mail: ostapko.dbs@mail.ru

Andrei L. Zolotoi

Post-graduate student of the Department of Natural Flora and Conservation of the Donetsk Botanical Garden, Donetsk, Ukraine, e-mail: andreyzolotoy08@mail.ru 